\title{
A invenção do espaço habitacional nas margens do Rio Capibaribe do Recife: relações de lugar e de visibilidade
}

\author{
Normando Jorge de Albuquerque Melo ${ }^{l}$
}

\section{Introdução}

A cidade, prostituta puritana, é o grande advento da humanidade. Nada, como a cidade, serviu tanto ao intuito de controlar as relações de visibilidade dos grupos. Tudo na cidade é esconder e mostrar, sedução fatal. $\mathrm{O}$ belo, que é sempre moral e limpo, toma o lugar do feio-imoral e sujo, que a cidade se envergonha de ter criado. A maquiagem infra-estrutural do urbano esconde o feio e evidencia o belo. Tudo: da iluminação pública até a sua distribuição espacial (e aí de maneira mais contundente), serve a este propósito. A cidade ergue-se escondendo as marcas que ela mesma produziu, mantendo confinado no calabouço do inconsciente visual, tudo que testemunha contra ela.

Assim como os microorganismos suspensos no ar circundante, que Pasteur vislumbrou (COHN, 1987), sob o asfalto e o concreto existem mundos; os mundos que a cidade deixou órfãos, filhos, que se negou a assumir. Todo o instrumental tecnológico que a humanidade conseguiu desenvolver: da lente mais arcaica à mais moderna, do microscópio mais potente à câmera mais simples, nada conseguiu aumentar o nosso poder de visão. Continuamos sob o mesmo manto da impotência óptica. A cidade cria barreiras visuais tão poderosas que podemos passar vinte, trinta, quarenta anos, morando em um mesmo lugar sem jamais nos darmos conta desses mundos, ainda que estejam no nosso quintal.

Estas barreiras não se resumem aos obstáculos físicos que nos são impostos, também devemos levar em consideração o fator psicossocial. O ritmo acelerado da cidade, o grande número de estímulos de ordens variadas ao qual somos expostos, exige muito de nossas capacidades perceptivas. Tal conjunto de coisas nos leva à atitude blasé ${ }^{1}$, que afeta o nosso poder de discriminar. Isto não quer dizer que os objetos em geral não sejam percebidos, mas esta percepção é de nível inferior, apenas fisiológico. Os objetos são percebidos como ausentes de conteúdo devido ao embotamento da percepção.

Benjamin chama a atenção para um recurso da câmera. Segundo ele, "a câmara com seus inúmeros recursos auxiliares, suas imersões e emersões, suas interrupções e seus isolamentos, suas extensões e suas acelerações, suas

\footnotetext{
' Graduação - Ciências Sociais da UFPE

' “A atitude blasé resulta em primeiro lugar dos estímulos contrastantes que, em rápidas mudanşas e compressāo concentrada, são impostos aos nervos" (SIMMEL, in: VELHO, 1979, pl6).
} 
ampliações e suas miniaturizações [...] nos abre, pela primeira vez, a experiência do inconsciente óptico, do mesmo modo que a psicanálise nos abre a experiência do inconsciente pulsional" (1986, p189). Mas para que a câmera possa cumprir o seu papel histórico, é necessário que os olhos se antecipem às lentes. Primeiro precisamos perceber individualmente a nossa imagem, para que depois possamos oferecê-la à percepção coletiva.

A literatura também permite a apropriação da percepção individual pela coletiva. Mas a imagem, além de ser o meio mais eficiente de comunicação, também é o que conserva maior potencial de pureza e objetividade. Josué de Castro utilizou-se da escrita para dar visibilidade ao mundo faminto que pululava na frente da sua casa, mas nunca deixou de pensar no cinema como veiculador da imagem que se agarrou aos seus olhos até o fim da vida: a imagem da miséria nos mangues do Recife. Se Josué de Castro descobriu a fome nos seus "anos de infância" (CASTRO, 1967, p12), não é assim sempre. Ainda que tudo nas crianças seja estranhamento, o ver é exercício hercúleo. Ver é antes de tudo estranhar. O cientista tomou esta atividade para si.

Trataremos aqui de duas destas marcas localizadas ao longo do Rio Capibaribe do Recife. Ambas dizem respeito ao mesmo tipo de fenômeno habitação - embora conservem suas peculiaridades enquanto processos distintos. O rio corta a cidade do Recife como uma grande ferida aberta que o tempo não sanou. Percorrer o rio é conhecer a cidade por dentro. É ver nas suas margens, as marcas que o rio não conseguiu apagar.

De uma destas marcas, a Comunidade da Benfica, tomei conhecimento ainda criança, éramos vizinhos. Ela representa uma estratégia habitacional bastante comum na paisagem do Recife: as palafitas. Da outra, a Ponte do Limoeiro, quando captava imagens do mangue da Rua da Aurora, no centro da cidade do Recife, para um vídeo ${ }^{2}$ que estava a realizar sobre os símbolos que Josué utilizou para representar o mangue. A poucos metros de onde eu estava uma ponte servia como casa para cerca de 42 pessoas. O espaço se reinventava, tijolo por tijolo, aquele mundo se constituía sob as rodas dos veículos, leves e pesados, que atravessavam a ponte sem jamais se dar conta do que acontecia. E o que acontecia, é que dentro daquela ponte, não acima, não embaixo, mas dentro; pessoas comiam, dormiam, viviam, moravam.

A observação foi orientada para quatro aspectos do processo de invenção do espaço: o antes, a chegada, o durante e o depois. Uma perguntachave foi formulada para cada um destes temas: Como era a vida antes daqui? Como foi a chegada aqui? Como é a vida aqui? O que você espera do futuro? A partir das respostas obtidas, perguntas mais específicas eram feitas de forma a

2 "Festa do Mangue"- 2001. 
aprofundar alguns temas: trabalho, crianças, etc $^{3}$. Os contatos nas comunidades foram feitos com os moradores mais antigos, depositários da memória ${ }^{4}$ do lugar.

Durante a observação foram utilizados recursos áudio-visuais, que permitiram a produção de um vídeo: "Barracas da beira da maré: a invenção do espaço habitacional nas margens do Rio Capibaribe do Recife", que é um conjunto de depoimentos e imagens do lugar e das pessoas realizando as mais diversas atividades, costurados de forma a seguir o curso do rio. Já que o projeto foi fundamentalmente inspirado no "Homens e Caranguejos" de Josué de Castro" (1967), tudo nele deveria acompanhar o rio, "linearidademeandrante".

As características próprias do objeto, aqui um grupo estigmatizado, podem gerar desconfortos na interação com o pesquisador ${ }^{5}$. Sendo uma relação interpessoal, o pesquisador explicitará suas intenções e, nelas, estarão implícitas as causas que despertaram o seu interesse; aparecerá então que, aquilo que me levou a você foi a diferença que existe entre nós. Em outras palavras, ver é antes de tudo estranhar, e esse estranhamento confirma, nestes casos, o estigma. A relação torna-se tensa para ambas as partes, segundo Goffman (1975), no entanto, se ela conseguir se manter, poder-se-á esperar que a marca perca sua capacidade de intrusão.

Neste contexto, a câmera é um personagem pícaro. Ou afasta totalmente o pesquisador do pesquisado, ou os deixa a uma distância igual à espessura da lente. Ora, o estigmatizado, busca esconder a sua marca, é então de se esperar que um instrumento tal como a câmera cause repulsa. Pelo contrário, a escuridão a qual eles são submetidos, deixa latente uma grande necessidade de voz que gera uma predisposição à interlocução. Dessa forma, o indivíduo que apontava para o pesquisador como alguém que lhe via como diferente, escondia o medo de não ser visto. A câmera então, lhes colocava na televisão como nas novelas da Globo, lhes valorizava, lhes dava atenção irrestrita. Eles se tornavam protagonistas de suas próprias histórias.

Estas histórias envolvem relações de lugar e de visibilidade, recorrentes em todo o texto, dividido em quatro momentos. Este primeiro, mais introdutório, no qual tenta-se explicitar a natureza do trabalho; e o último, de caráter conclusivo, no qual serão tecidas algumas considerações finais. No

\footnotetext{
${ }^{3}$ Além das perguntas mais específicas, não foram descartadas as "conversas de cisterna", nas quais o pesquisador é envolvido nos problemas da comunidade como se dela fizesse parte, no que eu chamo de "esforço de fraternalização".

${ }^{4}$ Notou-se uma perda da noção de tempo, principalmente na Benfica, onde os moradores não possuíam clareza quanto ao tempo em que estavam lá.

3 Josué trabalha personagens que têm uma história, que chegaram e que vivem no mangue de uma ou outra forma, e que têm "desejos" ou nảo.

${ }^{5}$ Entendo que estes elementos não devem ficar fora do trabalho científico.
} 
segundo momento, "O Recife e a formação do espaço", o mais longo, expomos os processos que engendraram a paisagem que tomamos agora como objeto. Em seguida, no "Escadas e corredores", nos deteremos mais especificamente no caso da Comunidade da Benfica e da Ponte do Limoeiro.

\section{O Recife e a formação do espaço}

Assim como Josué de Castro, a minha paisagem é o mangue do Recife. O melhor exemplo da imposição de uma ordem ética e estética em um espaço, é o Recife, uma cidade planejada pelos holandeses (na conquista, um "pobre arraial de pescadores"), mas que resulta não-planejada (SANTOS, 2001) e que se olha, como Narciso, nas águas de seus rios. Recife é pura reivindicação de beleza e de espaço. "O fundamento da cultura do Recife é o espaço, em seu sentido amplo" (BERNARDES, 1996, p128). Um espaço de lutas, que remetem ao processo de construção deste espaço. "Uma luta líquida. De água salgada contra água doce e vice-versa. De espasmos da terra ainda verde. De um mundo procurando se ajustar. De se firmar. De se estabilizar" (BEZERRA, 1965, p21). E uma luta do homem por este espaço.

Essas extraordinárias lutas foram levadas com toda a poesia para os livros que tenho citado. Mas nenhum deles tem a força do "Homens e Caranguejos", de Josué de Castro. E ainda não será nele que, encantado com o processo de formação do Recife, escreverá: "Recife, telhados, torres e cúpulas. Ondulações. Ruínas históricas. Lendas portuguesas, holandesas e afrobrasileiras. Recife, azuleijado lavado de luz, à sombra dos coqueiros, boiando nas águas" (CASTRO, 1937, p20).

O Recife ergue-se quase dentro da água. Uma cidade anfíbia, como Amsterdã e Veneza. "A cidade assenta nas terras baixas de uma extensa planície aluvional [...] constituída de ilhas, penínsulas, alagados, mangues e paúis, envolvidos pelos braços dos rios que [...] se espraiam remansosos pela planície inundável" (Id, 1948, p16). Planície formada pela ação destes rios, como depositadores de sedimentos aluvionais, naquela bacia que no passado teria sido sua foz (GALVÃO FILHO apud CHACON, 1959).

Mas esta "ciclópica atividade arquitetônica da criação do solo do Recife", como diz Josué de Castro (1948), coube também ao mangue, especializado em terras alagadiças e salobras, que recobria a área hoje ocupada pela cidade do Recife. Vegetação náufraga, que luta contra a sede em meio a água, o mangue foi o primeiro colonizador do espaço que ali se inventava, só depois o fator humano veio colaborar. "Procurando consolidar o seu habitat para resistir ao ímpeto variável das correntes, os mangues acabam por consolidar todo o trato de solo-incerto, onde começam a proliferar. A fixação da planta faz-se através de um complexo sistema radicular, extenso e 
intrincado" (Ibid, p21). O mangue se fixa no solo como um morador na sua morada, ambos reivindicam o seu lugar.

E boiando nas águas, o Recife, ainda um patinho feio ${ }^{6}$ nas mãos dos portugueses, que preferiam Olinda aos baixios recifenses, cantou e encantou. Primeiro atraiu os holandeses. Tomarei este fato como exemplo da topofilia, "do elo afetivo entre a pessoa e o lugar ou ambiente físico" (TUAN, 1980, p5). Havia inúmeras semelhanças entre as duas paisagens, holandesa e recifense: identidade topográfica (em que confirma-se o mesmo trabalho ciclópico na formação do espaço) e uma cultura eminentemente espacial, forjada na luta pelo espaço. "Nenhum povo do mundo fora sempre tão obrigado a pensar nos problemas do seu solo quanto o povo holandês, sempre ameaçado, de perdê-lo, numa permanente luta com o mar" (CASTRO, 1948, p40).

Ora, não estou aqui ignorando os fatores econômico-estratégicos na formação da preferência holandesa pelo Recife. Mas por que os portugueses preferiram Olinda ao Recife? Por que os holandeses, ao terem conquistado Olinda, preferiram destruí-la à ocupá-la? "O meio ambiente pode não ser a causa direta da topofilia, mas fornece o estímulo sensorial que, ao agir como imagem percebida, dá forma às nossas alegrias e ideais" (TUAN, 1980, p129). Tuan ainda nos diz que: "Para compreender a preferência ambiental [...] no nível de atitudes e preferências de grupo, é necessário conhecer a história cultural e a experiência de um grupo no contexto de um ambiente físico. Os conceitos cultura e meio ambiente se superpõem do mesmo modo que os conceitos de homem e natureza" (Ibid, p68).

"O flamengo preferiria o Recife pela mesma razāo que os portugueses escolheram Olinda: suas categorias culturais movimentam-se melhor numa moldura ecológica determinada. Num caso os baixios próprios ao seu temperamento de 'povo anfíbio' formado nos 'polders' seculares dos Países Baixos; noutro as recordaçōes das táticas guerreiras de país montanhoso onde proliferam os castelos dominando do alto as planícies. Tanto aqui como lá o sentido de defesa dos seus bens. No que se refere a esta regiảo brasileira, a guarda ciosa do açúcar precioso da várzea do Capibaribe, capaz de dar bom preço em mercados europeus, apesar das crises, do contrário evidentemente não o cultivariam" (CHACON, 1959, p29). Olinda não conseguiu conquistar a simpatia dos novos conquistadores.

Segundo Josué de Castro (1948), a água, ou melhor dizendo, fatores ligados a água, teriam sido definitivos na escolha da Ilha de Antônio Vaz para dar suporte à nova cidade. Tratava-se de uma ilha situada entre o Capibaribe e o Beberibe, por onde era escoada a produção açucareira até o porto, uma situação ideal. "As ilhas sempre fascinaram os holandeses como bases naturais onde

\footnotetext{
${ }^{6}$ Constituía-se apenas de um porto que escoava a produção canavieira da várzea do Capibaribe, de armazéns para estocagem e de um pequeno arruado de casebres em torno da Ermida de S. Telmo santo querido dos pescadores.
} 
levantar cidades, por thes pouparem o esforço de cavar fossos defensivos em todos, ou, pelo menos, em alguns dos lados dos seus núcleos urbanos" (Ibid, p53). Junte-se a isto, a água para o abastecimento da cidade que podia ser encontrada no seu subsolo.

\begin{abstract}
"Antes da chegada dos holandeses, não havia ainda no local traços significativos de uma futura cidade" (Ibid, p35). Havia sim aquele pequeno povoado que já mencionei, sob a proteção de Santelmo, protetor das gentes do mar contra as tempestades. "Antes dos holandeses o povoado recifense não tinha nem estado de espírito, nem 'status' de cidade. O invasor nórdico trouxe-os" (CHACON, 1959, p73).
\end{abstract}

Os holandeses que para cá vieram eram homens da cidade, urbanos, cosmopolitas, em sua maioria judeus vítimas de perseguição religiosa. O espírito urbano holandês instala-se no Recife primitivo que nascia para atender ao porto. "Os flamengos, com as pontes, palácios de Nassau, homens ilustres como os da comitiva do conde, planos de urbanização, etc. transmitiam à aldeia a 'consciência', o 'status' de cidade” (Ibid, 55). A pressão demográfica, a prosperidade econômica e aquele estado de espírito do qual nos fala Robert Park $^{7}$, herdado dos holandeses, fizeram crescer a planície do Recife, que sobrepujou todas as vilas da capitania e se tonou capital.

E boiando nas águas, mas agora como a mais bela sereia do Atlântico ${ }^{8}$, o Recife continuava a cantar e a encantar. Seu canto chegou à zona rural de Pernambuco, e encantado, o homem do campo que em princípio só deixava a sua terra quando sob o flagelo da seca, agora o fazia buscando a infra-estrutura que sua terra lhe negava. E o Recife, florescente capital do Nordeste, atraía carregamentos humanos de toda a região. Uma verdadeira-falsa Terra Prometida.

A cidade crescia às pressas ${ }^{9}$, desordenadamente, e aos que vinham de longe, "de terras distantes em busca de um pedaço de chão desocupado onde deitar raízes [...] retirantes das secas, tangidos pelo vento de fogo do sertão" (CASTRO, 1967, p38), restava os alagados, que depois lhes seriam tomados ou utilizados como meios de exploração. No Brasil, a política de terras dava margem tanto para os particulares cobrarem foros de terras que não lhes pertenciam, como também, para que se ocupassem terras sem nenhuma formalidade. No Recife, o sistema de "invasões" ocorria principalmente nos alagados, fato que se dava pacificamente antes da grande valorização das terras.

Inúmeros fatores contribuíram para o grande número de aforamentos de terrenos de marinha e dos que se inventavam sobre os mangues do Recife:

\footnotetext{
${ }^{7}$ PARK, R. in: VELHO, 1976.

${ }^{8}$ Já livre da presença holandesa.

${ }^{9}$ Afundando lentamente.
} 
"O interesse de certas indústrias ou comércio que se localizaram às margens das áreas banhadas pelas águas salgadas. Assim, poderiam receber e embarcar os produtos e mesmo expelir os resíduos imprestáveis do seu fabrico ou comércio. A venda de madeira dos mangues, para aproveitamento nos cortumes e nas grandes fornalhas ou mesmo nos lares mais modestos também despertou o desejo de aforar essas terras elameadas. Houve, ainda, os aforamentos para formação dos "viveiros", cujas curimans e camurins, neles criados, têm um sabor inigualável e aqueles que se fizeram para obter sítios onde existiam coqueiros, cajueiros e mangabeiras. É certo que alguns indivíduos perceberam, com grande antecedência, que a valorização destas terras chegaria mais cedo ou mais tarde. Valeram-se, por isso, da sua posiçâo social e financeira e aforaram ou ocuparam grandes áreas. Algumas ordens religiosas também obtiveram este privilégio. Crescia então a cidade. Abriam-se ruas e avenidas e estradas. Fazia-se aterro, invadindo-se os mangues e disputando até com sangue as terras afogadas do Recife" (BEZERRA, 1965, pp38-39).

"Sobrecarregada a planície, a valorização da terra e dos mangues ocorreu como um acontecimento natural [...] bom negócio aterrar mangues e loteá-los ou mesmo loteá-los sem aterrar" (Ibid, p39). Essa atividade cabia ao mocambeiro, foi ele quem de fato inventou o espaço do Recife, que beneficiou a área com suas casas de palha, tábua ou pau a pique. Vindos de longe, com poucas ou nenhuma posse, os alagados se mostravam como única saída. "Ś o mangue e o mocambo estavam à altura de suas posses" (CASTRO, 1967, p99). “...no mangue não se paga casa, come-se caranguejo e anda-se quase nú” (Id, 1937, p27-28).

Morar nos alagados mostrava-se extremamente estratégico. $\mathrm{O}$ rio não era apenas um aspecto pitoresco da paisagem do Recife, como talvez seja hoje, configurava-se como um elemento de importância social, cultural e econômica. As margens do Capibaribe eram amplamente valorizadas, a cidade erguia-se nas suas cercanias, as casas tinham a frente voltada para o rio, o rio servia como via de comunicação urbana, como espaço de lazer com seus vários sítios de banho. Ora, morar "no rio" era estar na cidade, integrar-se a ela, fazer parte estando perto. A precariedade da casa era camuflada pela infra-estrutura do entorno, onde estes moradores trabalhavam: na atividade doméstica (nas casas ricas) ou na execução de pequenos serviços. Josué (1967) ainda amplia este leque, ao considerar os alagados como um espaço que concede invisibilidade aos seus moradores, o que atrairia pessoas que buscam algum tipo de isolamento ou anonimato ${ }^{10}$.

"Daí porque, quando a redefinição do espaço urbano trouxe a valorização de tais áreas, ou quando projetos governamentais implicavam na expulsão de seus moradores ", uma tâo forte resistência surgiu. Pois a mudança de moradia, mesmo que para casa de melhor padrão, significava a distância das fontes de emprego e sobrevivência mais imediata e a

\footnotetext{
${ }^{10}$ Retomarei este ponto.

${ }^{11}$ Ação que não visava a melhoria das condições de vida daquele morador.
} 
oneração do custo de transporte[e da casa como um todo $]^{12}$, antes em certos casos, até inexistente" (BERNARDES, 1996, p135).

Os mocambeiros fixavam-se naquelas terras, enraizados como os mangues, trazidos pelos rios como os aluviōes. Ora, eles não construíram apenas as suas próprias casas, eles eram também, os inventores daquele espaço, do chão que ocupavam. "Construir é um ato religioso, o estabelecimento de um mundo em meio de uma desordem primeva” (TUAN, 1983, pp116-117). Eles não criaram menos que um mundo. Eis que nos deparamos novamente com o fator topofílico. O caráter sagrado do ato de construir, o esforço de ordenação do caos, a luta (trabalho) travada todos os dias pela manutenção do espaço ${ }^{13}$, tudo isto que alimenta a topofilia. Eis porque o Recife é o mais adequado campo para esta observação, e será entre as categorias mais pobres da população, que encontraremos uma relação mais integrada com os baixios, os rios e os mangues, com o espaço do Recife. Elementos que propiciam a subsistência de grande parcela dos mocambeiros.

Mas ao mesmo tempo em que os oferecia casa e comida, o mangue os consumia, lhes roubava a alma. Aos poucos, atolando lentamente, os homens iam se juntando aos caranguejos, se misturando à lama. "Os mangues iam, assim, se apoderando da vida de toda aquela gente, numa posse lenta, tenaz e definitiva" (CASTRO, 1967, p13). Josué de Castro se refere a este processo como o "Ciclo do Caranguejo":

“Os mangues do Capibaribe são o paraíso do caranguejo. Se a terra foi feita para o homem, com tudo para bem servi-lo, também o mangue foi feito especialmente para o caranguejo. Tudo aí, é, foi ou está para ser caranguejo, inclusive a lama e o homem que vive nela. A lama misturada com urina, excremento e outros resíduos que a maré traz, quando ainda não é caranguejo, vai ser. $\mathrm{O}$ caranguejo nasce nela, vive dela. Cresce comendo lama, engordando com as porcarias dela, fazendo com lama a carninha branca de suas patas e a geléia esverdeada de suas vísceras pegajosas. Por outro lado o povo daí vive de pegar caranguejos, chupar-lhe as patas, comer e lamber os seus cascos até que fiquem limpos como um copo. E com a sua carne feita de lama fazer a carne do seu corpo e a carne do corpo de seus filhos. São cem mil indivíduos, cem mil cidadãos feitos de carne de

${ }^{12}$ Grifo meu.

${ }^{13}$ Seja contra o elemento natural: quando as águas retornam para retomar seu espaço; seja contra o elemento humano espoliador: "Quando a pressâo econômica, social, política, cultural e até policial dos adversários tornou-se muito forte, violenta mesmo, prenunciando esmagar núcleos inteiros, como ocorreu com alguns mais fracos, mais desafortunados, eles criaram 'sociedades' para defender os seus modestos interesses habitacionais" (BEZERRA, 1965, p41). 
caranguejo. O que o organismo rejeita, volta como detrito, para a lama do mangue, para virar caranguejo outra vez" (Id, in: MANÇANO, WALTER, 2000, p43).

Essa alegoria não é sem sentido. "A água é uma imagem do inconsciente; ela é amorfa mas fertilizadora, uma fonte potencial de força. A água simboliza o lado feminino da personalidade humana. A imersão na água significa a extinção do fogo e da consciência. Significa morte" (TUAN, 1980, p26). Também Bachelard diz da água em Poe: "a água fornece o símbolo de uma vida especial atraída por uma morte especial" (1998, p50). Os primeiros conquistadores temiam a água abundante e a vegetação frondosa, tomavam esta paisagem como mortífera. Imagens de doenças e de crimes eram também associadas ao Capibaribe. As águas, sem dúvida alguma, provocam muitas imagens na gente do Recife, onde "o que não é água, foi água ou é recordação dela”(OLIVEIRA, W. apud CHACON, 1959, p28).

O Recife, espaço conquistado primeiro pelos mangues, depois pelos homens, conserva as marcas do seu passado. Marcas, que a cidade busca ocultar, e que são antes de tudo o "produto do feudalismo agrário que oprimia e explorava, há séculos, toda aquela pobre gente que acabava, um dia, preferindo o fedor dos mangues ao fedor das malocas dos engenhos, das novas senzalas fracionadas em torno das novas casas-grandes" (CASTRO, 1967, p99). O Recife. Cidade conquistada às águas. Dádiva das águas. Solidariedade líquida. Pacto fluido. Ilheidade roubada pelas pontes. A "Mucambópolis" de Mário Lacerda de Melo (apud CASTRO, 1948). Cidade suja de lama que o rio tenta lavar.

Estas marcas, símbolos de estigma ${ }^{14}$, estão espalhadas por todo o Recife, mas a cidade se ergue como poderosa adversária na luta pela visibilidade. "O problema dos alagados e mocambos a impressionará muito mais pelo lado da paisagem. Apresenta-se como uma chaga. Torna-se uma vergonha. Fere a vaidade coletiva. Choca-se com o complexo de superioridade de supremacia regionalista" (BEZERRA, 1965, p44).

Nestes termos, o indivíduo que carrega marcas, poderá se utilizar de alguns recursos para controlar a informação sobre a estas marcas, interferindo diretamente na percepção dos outros sobre o seu estigma. Este controle da informação, é antes o controle da relação de visibilidade. Caso não seja possível manter o estigma fora da relação, tamanha a sua capacidade de intrusão, o indivíduo estigmatizado poderá contar ainda com a baixa capacidade

\footnotetext{
${ }^{14}$ Segundo Goffman (1975), estigma é uma marca que transcende a dimensão corpórea e que traz o descrédito para o seu portador. Da mesma forma que existem símbolos de prestígio, existem símbolos de estigma.
} 
decodificadora da audiência ${ }^{15}$, que não reconhecerá o seu símbolo de estigma. Da mesma forma a cidade irá proceder.

Obviamente, o pleno controle das relações de visibilidade está longe de ocorrer e com o tempo, as marcas têm aumentado a sua capacidade de intrusão. Tenho chamado este movimento para a visibilidade de vazamento.

\section{Escadas e corredores}

A Ponte do Limoeiro, que liga Santo Amaro ao Brum, é a última ponte sobre o Rio Capibaribe. Sob ela, as águas deste rio e do seu irmão, o Beberibe, se encontram. Os vãos internos da estrutura da ponte têm servido como moradia para cerca de 42 pessoas, das quais 4 são pessoas sozinhas (sem companheiro e sem filhos) e o restante se divide em 10 famílias (com companheiro e com filhos $)^{16}$. Entende-se aqui, que há uma grande dificuldade em se pensar estes números, se não de uma forma muito flexível. A ponte se configura como um espaço misto: moradores, pescadores não-moradores e pescadores moradores. Quando o ser "morador" passa a ser o critério para inclusão nos projetos da prefeitura ou outro, esta categoria é reivindicada do mesmo modo que a antiguidade no lugar, ambas associadas à legitimidade.

Ainda não temos fontes seguras para afirmar há quanto tempo a Ponte do Limoeiro têm servido como moradia ${ }^{17}$, no entanto, sabemos como este processo começou. "Isso vem das antiga, porque antes a turma só guardava material aqui, entendeu? Agora tem moradia, mas antes só era material, só era para guardar material. Aí se serve para material, serve para morar...'(Edmilson - ponte). Nota-se claramente a perda da noção de tempo, que cai no "antigamente". Em outra fala, o processo é novamente narrado e o princípio (tempo) mantém-se imemorável. "Montar a casa, eu acredito que isso aqui tempos atrás, alguém já tinha tido a idéia né? De montar. Aí justamente em cima da precisão, eu procurei um meio né? De construir uma casa aqui, descobri essas pilastras, que ela é aqui no termino dela, ela é saindo para fora e favorece as pessoas a botar qualquer madeira que a madeira não desce né? Ela empata, e daí veio minha construção aqui, que não foi feito só num dia né?"'(Baiano - ponte).

\footnotetext{
${ }^{15}$ Em que contribuirá o embotamento da capacidade de discriminar.

${ }^{16}$ Estes números são da Prefeitura do Recife - Secretaria da Política de Assistência Social - que está desenvolvendo um trabalho com a comunidade através do "Programa de Atenção ao Morador de Rua". No dia 30 de outubro deste ano, os moradores da ponte foram transferidos para casas provisórias no próprio bairro, recebem uma bolsa moradia da prefeitura e estarão sendo capacitados para construírem suas próprias casas.

${ }^{17} \mathrm{O}$ morador mais antigo, Sr. Francisco Martins de Oliveira, reivindica 20 anos no lugar. Ainda não se conseguiu fazer contato com ele. Até então, o morador mais antigo, Baiano, tem 8 anos no lugar.
} 
Esta peculiaridade da estrutura da Ponte do Limoeiro, facilita a construção de um espaço para morar, sendo necessário apenas, as madeiras para o piso - conseguidas pelas ruas, ou negociadas nos armazéns das cercanias - já que o teto é o asfalto da ponte. "Ele arrumou o canto e eu arrumei as madeira"(Índio - ponte) ${ }^{\mathbf{1 8}}$. O calor é insuportável em qualquer horário do dia, dificultando a permanência nestes espaços. Os vãos, que têm uma média de 12 $\mathrm{m}^{2}$, são extremamente escuros e mal ventilados, alguns chegam a abrigar até 6 pessoas. Eles se estendem até o meio da ponte, os mais próximos da cabeceira não comportam um adulto de estatura mediana em pé. O acesso é feito por escadas de madeira, algumas delas mergulhadas no rio, fazendo com que as pessoas que moram nos vãos que se afastam da cabeceira, avançando para o meio da ponte, quando da maré alta, só possam entrar em casa utilizando pequenos barcos ${ }^{19}$.

Os moradores dispõem de alguma mobília e de eletrodomésticos. Os serviços domésticos (cozinhar, lavar roupa, etc.) são normalmente realizados fora de casa, embaixo da ponte. O calor torna impraticável cozinhar dentro de casa. A higiene pessoal também pode ser feita fora de casa, principalmente homens e crianças, que utilizam uma torneira fixada no alto como chuveiro. As necessidades fisiológicas são atendidas nos mangues do entorno. Há muito lixo em toda a parte. A falta de estrutura propicia a propagação de doenças como verminoses, desnutrição, anemia, dermatites de contato, etc. As principais vítimas são as crianças, não houve uma que não manifestasse algum tipo de lesão na pele. Muitas delas também, têm grandes cicatrizes na cabeça, provocadas sobretudo por queda, bastante frequentes, como os afogamentos. Dois, dos 3 filhos de Baiano, já caíram no rio, e seus nomes marcam este fato: Edmar e Edmário. Índio também conta episódio semelhante ocorrido com o seu filho: "aqui é um pouco perigoso para criança ficar subindo essas escadas... por sinal o meu caiu aí nessa maré aí cheia, só foi deus mesmo quem salvou e um pescador que tirou ele".

A atividade principal dos moradores da ponte é a pesca, seja no rio ou no mar. Neste sentido, a localização é ideal. A pesca, realizada apenas pelos homens, tanto aparece como única fonte de renda, como complementação à outra atividade. "A vida aqui, tem uns que são pescadores vive da pesca, já eu não sou pescador, eu vendo cuscuz de rua, aquele cuscuz do apito. Então, às vezes, sou obrigado a ser pescador também porque tem que entrar, porque o cuscuz não dá eu tenho que entrar pra dentro do mar e pescar também, já me acostumei aqui, já estou habituado à vida daqui, aqui é pesca". (Índio - ponte). Algumas atividades estão indiretamente ligadas à pesca, Baiano, por exemplo, toma conta dos barcos. A pesca e o trabalho informal nas ruas, e atividades

\footnotetext{
${ }^{18}$ Foi levado para Ponte por um amigo que morava lá.

${ }^{19}$ Estes barcos são conhecidos como "baiteiras".
} 
domésticas realizadas pelas mulheres, são a única alternativa à dificuldade do emprego. "Por mais honesto que nós seja, se a gente sair para procurar um emprego, e dizer eu moro dentro da ponte, já era" (Baiano - ponte).

A Benfica e a Ponte do Limoeiro são espaços diferenciados. Uma primeira tentativa de diferenciá-los de uma forma mais geral, seria a partir dos caminhos: o primeiro caracteriza-se por corredores, o segundo, por escadas. Outro aspecto, é o nível de dependência que os moradores da ponte têm com o espaço $^{20}$. Além disso, é estabelecida uma relação hierárquica entre estes dois espaços, a Benfica sente-se superior a Ponte. Em uma das falas, é dito que "é melhor morar aqui do que no meio da rua ou debaixo da ponte"'(Severina Benfica), embora não seja feita uma referência direta, nem se tenha a indicação de uma interação entre os moradores dos dois lugares. Essa mesma distinção entre espaços ocorre internamente na Benfica, a idéia de favela está associada à interiorização no espaço. Está em jogo também, a centralidade e a infra-estrutura de quem mora em um bairro nobre (Madalena), "que para pobre viver é uma beleza"(Geraldo - Benfica). O estigma de quem mora na Ponte é maior do que o de quem mora em palafitas, as casas nesta situação, configuram-se como casas normais, enquanto as outras são desviantes.

A Benfica é um estreito corredor com acesso único em torno do qual estruturam-se casas - ora só à direita, lado do rio, ora dos dois lados -; as pessoas que podem facilitar o nosso acesso ficam nos bares próximos à entrada da comunidade. O bar é verdadeiro ponto de encontro, quantas coisas deixaríamos de saber se nos negássemos a frequentá-lo e mesmo, "tomar uma" com o pessoal. Com isso, demonstra-se confiança. Se eles sentem que têm a nossa confiança, podem se sentir obrigados a fazer justiça à ela.

Em cada um desses espaços, como mencionei, o alvo eram os moradores mais antigos, que pudessem contar a história do lugar. Na Ponte do Limoeiro isto não era um problema, a fundação é atribuída aos pescadores que guardavam material no lugar. Na Benfica isto muda, um dos fatores que dificultam achar alguém que guarde a memória do lugar, é o alto grau de itinerância das famílias. É bem possível encontrar, em Engenho Maranguape ${ }^{21}$, alguém que saiba falar do passado da Benfica. Esse elemento pode surgir como um outro arranjo da pesquisa, se nos propusermos a estudar os laços que unem as comunidades espalhadas pelo Recife, região metropolitana e interior; uma verdadeira árvore genealógica. Mas por agora, não é este o caso.

A luta pelo espaço, não no sentido da especulação imobiliária, é mais forte na Benfica. A ponte desfruta de uma construção mais estável, morar na Benfica, significa antes de tudo: "Tem que tá sempre levantando, aqui mesmo

\footnotetext{
${ }^{20}$ Possuem um perfil diferenciado dos outros moradores de rua, vivenciam este espaço sem a mobilidade característica de quem está em via pública. A ponte os "protege".

${ }^{21}$ Comunidade situada na Região Metropolitana do Recife.
} 
muitos barraco aqui são levantado porque muito tempo que fica na lama, os pau vai afundando dentro da lama e realmente tem que levantar de novo"(Ubiratan - Benfica). "Sempre tem que tá botando um preguinho aqui um pausinho ali, essa aqui mesmo tava pela misericórdia para consertar, mas é de madeira é mais fácil, a gente vai ali tá desmanchando uma casa, olha ali tem um bocado de madeira no lixo, aí a gente pega um carro de mão, pega uns vizinho, vai traz uma tuia de pau e assim vai, não tem cimento não? Pega um pedaço de pano um pedaço de tapete, e assim vai..."(Severina - Benfica).

Essa luta pela manutenção do espaço é um grande fator de topofilia, da mesma forma que a dependência, mesmo material, dos moradores da ponte. As insatisfações dos moradores dos dois lugares, ainda que grandes, não ganham eco. Ninguém recusa uma casa em outro lugar - na realidade, gostariam de ter uma casa fora, mantendo a que já possui - ninguém manifesta forte desejo de sair. Mas o "gostar" do lugar, pode não passar de uma adaptação à necessidade de sobrevivência. "O que é ruim aqui é porque quando é época de chuva, alaga né? Alaga e vamos supor... a maré alta. Entendeu? Aí se você, vamos supor, você guardou um pão, você tem que guardar bem guardado, se você não acomodar aquele pão bem guardado, você no outro dia vai ter que jogar, porque o rato vem. Isso sobe em cima da mesa, sobe no fogão, se você deixar uma panela em cima do fogão tem que tirar, porque o rato vai lá. Entendeu? É isso aí. E não é rato não, é gabiru, é. Aqui, eu to aqui em pé, se eu não ficar atenta ele passa aqui, (pisht), na semana passada ele arranhou minha perna, o gabiru, é a gente tem que tá ói, alerta, ele vai para cama, ele vai para cama, é. A gente tá dormindo quando vê ele passa por cima da gente com medo da gente, é uma coisa, mas é bom, é perto de bompreço, mercado, farmácia, é bom demais aqui, é muito bom, a gente tá aqui de enxerido né?"'(Severina - Benfica). O lugar oferece a vantagem do anonimato, vida barata e proximidade às agências de obras sociais e missões, contando com a infra-estrutura de um bairro nobre.

A questão da discriminação é recorrente na Benfica e na ponte. "Aqui a gente é excluído como bicho, aqui as pessoas passam por cima aí, deixam tão claro que quando eu comecei a armar aqui, um negócio aqui, a prefeitura veio e derrubou e disse não porque fica chato as pessoas que passam aqui de barco, de lancha de passeio, vê as escadas mas não vê que tem uma moradia tá entendendo? E se você pondo isso aí vão saber que aqui tem alguma coisa e pode na curiosidade ver que é morador, pessoas que moram aqui embaixo. Tá compreendendo? Para esconder o sujo né?"'(Baiano - ponte).

Esta é a problemática central deste estudo. A partir disso, nos permitiremos algumas consideraçōes, que menos que uma conclusão finalizadora, serão um comentário sobre o que Baiano, morador da ponte, nos fez ver com a sua fala. 


\section{Conclusão}

Foram inúmeros os elementos que surgiram durante as entrevistas. A separação moral dos grupos que compõem as comunidades, as estratégias gerais para lidar com as circunstâncias do ambiente e construir a casa, a questão da exclusão (com muita intensidade), da relação da comunidade com o entorno e com o próprio espaço, o trabalho, a mudança de lugar, e o assistencialismo (embora não tenha sido considerado aqui). Tais elementos deram margem a algumas reflexões, que nos permitiram trabalhar as categorias de espaço-lugar e visibilidade relacionando-as com a de pureza, que foi rapidamente mencionada aqui, mas que ganhou força na voz de Baiano. Foi a fala dele que relacionou, pela primeira vez, os três elementos.

O que poderá parecer uma ruptura neste texto, introduzindo já ao final um elemento novo, é crucial para os propósitos deste trabalho. A súbita ênfase dada aqui à questão da pureza relaciona-se a um acontecimento do início do campo. Quando entrei em contato pela primeira vez com os moradores da ponte, estava com as pernas recobertas de lama em função da realização do primeiro vídeo. Antes mesmo de chegar aos moradores, um menino veio a mim e disse que as minhas pernas estavam sujas. Estranhei e busquei o que estava por trás daquele sinal. Ora, eu não era dali, não podia estar com lama no corpo, a lama tinha o seu lugar e em mim ela estava fora do lugar. Naquele momento dei-me esta explicação, estaria tentando eu me passar por um deles quando fui descoberto? Que antropólogo vai à uma tribo de cocar?

Percebi, depois, que não era daquela forma. A lama realmente tinha o seu lugar, mas mesmo eles, tão em contato com a lama, consideravam-na sujeira em qualquer parte do corpo que não fosse a sola dos pés. O rio lhes servia como purificador, lavavam-se em suas águas. Já em contato com os moradores, um deles, Baiano, deu-me a palavra final sobre o assunto em dois aspectos: relações de pureza e relações de visibilidade. Primeiro ele conta que quando construía uma pequena passarela sob a ponte, para poder entrar em casa sem passar pela lama, a prefeitura o proibiu, o que ele tomou como "para esconder o sujo"; os moradores da ponte não poderiam dar indícios de que moravam lá. Depois ele retoma suas palavras, dizendo que não se sente humilhado em morar lá, e que "ser pobre não é vergonha, vergonha é ser seboso".

A exclusão, que se dá em prol de uma identidade, é baseada em critérios de pureza. Uma identidade constitui uma certa ordem, e aquilo que difere, que diverge, que pode trazer instabilidade e desordem para o grupo, é 
tomado como impuro. A impureza é portanto, uma categoria de desordem ${ }^{22}$. Para evitar que a pureza fique em perigo, o poder manifesta-se sob a forma de controle das relações de visibilidade, ainda que se utilize das distâncias para conseguir este intento. Ora, o sujo contagia e o primeiro contato com o impuro é realizado pelos sentidos, principalmente pela visão. O principio ativo da impureza precisa ser separado dela, de forma a destituí-la do seu potencial de contágio. A cidade opera esta lógica, comum a todos os grupamentos humanos, excluindo o sujo do espaço visual.

Esta é, sem dúvida, uma discussão que não pode ficar fora da agenda das politicas urbanas.

\section{Referências Bibliográficas}

BACHELARD, Gaston. A Água e os Sonhos: ensaios sobre a imaginação da matéria. São Paulo: Martins Fontes, 1998.

BENJAMIN, Walter. A obra de arte na era de sua reprodutibilidade técnica in: Obras escolhidas: magia e técnica, arte e politica. São Paulo: Brasiliense, 1986. (p 165-196).

BERNARDES, Denis. Recife: o caranguejo e o viaduto. Recife: Ed. Universitária UFPE, 1996.

BEZERRA, Daniel Uchôa Cavalcanti. Alagados, mocambos e mocambeiros. Recife: Imprensa Universitária, 1965.

CASTRO, Josué de. O Ciclo do Caranguejo in: MANÇANO, B. WALTER, Carlos. Josué de Castro: vida e obra. São Paulo: Expressão Popular, 2000. (p 41-44).

1937.

. Documentário do Nordeste. Rio de Janeiro: José Olympio, . Fatores de localização da cidade do Recife: um ensaio de Geografia Urbana. Brasil: Imprensa Nacional, 1948. . Homens e Caranguejos. São Paulo: Brasiliense, 1967.

CHACON, Vamireh. O Capibaribe e o Recife: história social e sentimental de um rio. Recife: Secretaria de Educação e Cultura de Pernambuco, 1959. COHN, Gabriel (org). Comunicação e Indústria Cultural. São Paulo: T. A. Queiroz, 1987.

GOFFMAN, Erving. Estigma: notas sobre a manipulação da identidade deteriorada. Rio de Janeiro: Zahar, 1975.

DOUGLAS, Mary. Pureza e perigo. São Paulo: Perspectivas, 1976.

PARK, Robert Ezra. In VELHO, Otávio (org). O Fenômeno Urbano. 4 ed. Rio

22 "A sujeira ofende a ordem. Eliminá-la não é um movimento negativo, mas um esforço positivo para organizar o ambiente" (DOUGLAS, p12) 
de Janeiro: Zahar, 1979. (p 26-67).

SANTOS, Paulo. Formação de Cidades no Brasil Colonial. Rio de Janeiro:

Editora da UFRJ, 2001.

SIMMEL, Georg. A Metrópole e a vida mental. In: VELHO, Otávio (org). $O$

Fenômeno Urbano. 4 ed. Rio de Janeiro: Zahar, 1979. (p 11-25).

TUAN, Yi-fu. Topofilia: um estudo da percepção, atitudes e valores do meio ambiente. Rio de Janeiro: Difel, 1980.

1983. . Espaço e lugar: a perspectiva da experiência. São Paulo: Difel, 